nghiên cứu cũng tương đồng với các nghiên cứu khác liên quan đến hoạt động của điều dưỡng trong mối quan hệ với đồng nghiệp trong bệnh viện.

\section{KẾT LUÂN}

Tỷ lệ Điều dưỡng trưởng khoa đủ năng lực quản lý chung vẫn ở mức trung bình là $57,4 \%$, trong đó các năng lực yếu nhất là quản lý chuyên môn, tiếp theo đó là quản lý nguồn nhân lực, quản lý y đức và văn hoá phục vụ, quản lý môi trường làm việc, mặc dù năng lực quản lý cơ sở hạ tầng có kết quả cao nhất nhưng cũng chỉ chiếm $42,6 \%$

\section{TÀI LIỆU THAM KHẢO}

1. Bộ Y Tế. Chuẩn năng lực cơ bản của Điều dưỡng Việt Nam, (2012).

2. Bộ Y Tế. Tài liệu Quản lý Điều dưỡng. Hà Nội: Nhà xuất bản Y Học; 2004.
3. Sở Y tế Lào Cai. Báo cáo nhân lực y tế tỉnh Lào Cai năm 2019. Lào Cai: 2019.

4. Bùi Thị Bích Ngà. Thực trạng công tác chăm sóc của điểu dưỡng qua nhận xét của người bệnh điều trị nội trú tại bệnh viển $Y$ học cô truyền Trung ương năm 2011. Hà Nội: Trường Đại học Y tế công cộng; 2011

5. Tỉnh ủy Lào Cai. Đề án 7- Đề án Phát triển y tế, chăm sóc và nâng cao sức khỏe nhân dân, giai đoan 2016 - 2020. Lào Cai: 2015.

6. Dương Thị Thanh Huyên. Đánh giá kết quả hoạt động quản lý của điều dưỡng trưởng tai các cơ sở y tế tuyến huyên tỉnh Nam Định năm 2019. Tạp chí Khoa hoc Điếu dưỡng. 2019; 3(2):76-85.

7. Dương Thị Bình Minh. Thực trạng công tác chăm sóc điêuu dưỡng người bệnh tại các khoa lâm sàng bênh viên Hữu nghị Tạp chí $Y$ học thực hành. 2013;876(7):125-9.

8. Bùi Thị Bích Ngà. Thực trang công tác chăm sóc của điều dưỡng qua nhân xét của người bệnh điều trị nội trú tại bệnh viển $Y$ học cố truyền Trung ương năm 2011. Hà Nội: Trường Đại học Y tế công cộng; 2011.

\title{
ĐĂC ĐIỂM LÂM SÀNG, CÂN LÂM SÀNG Ở BÊNNH NHI BỊ RẮN CHÀM QUẠP CẮN TẠI BỆNH VIỆN NHI ĐỒNG 1
}

\section{TÓM TẮT}

Mục tiêu: Xác đinh đặc điểm lâm sàng và cận lâm sàng ở bệnh nhi bị rẳn chàm quạp cắn nhập Bệnh viện Nhi đồng 1 . Phương pháp nghiên cứu: Nghiên cứu hàng loạt ca trên 54 trẻ bi rắn chàm quạp cắn nhập khoa Cấp cứu, Bệnh viện Nhi đồng 1 từ ngày $01 / 01 / 2011$ đến ngày $31 / 12 / 2020$. Kết quả: Gần $100 \%$ trường hợp sưng nề và đau tại chố, dấu móc độc $72,2 \%$. Tỉ lệ nhiễm trùng và hoại tử vết thương khá cao $(37,0 \%$ và $38,9 \%)$. 44,4\% xuất hiên bóng nước và khi có bóng nước thì $100 \%$ có xuất huyết trong bóng nước. Có mối tương quan giữa bóng nước, nhiễm trùng, hoai tử với mức đô nhiễm độc ( $\mathrm{p}<$ $0,001)$. Bầm máu $55,6 \%$, chảy máu vết cắn $46,3 \%$, xuất huyết da $46,3 \%$, chảy máu nướu răng $14,8 \%$, xuất huyết tiêu hóa $1,9 \%$, thiểu niệu $(1,9 \%)$, hạ huyết áp $(1,9 \%)$ chủ yếu gặp ở bênh nhân nhiễm đọ̉ nặng. Có mối tương quan giữa bẩm máu, chảy máu vết cắn, xuất huyết da với mức độ nhiếm độc ( $\mathrm{p}<$ 0,001). Vết thương lan rộng qua 2 khớp 55,5\%. Rối loan chức năng đông máu là biểu hiện thường gặp $94,6 \%$, trong đó DIC chiếm 57,5\% với fibrinogen giám < $1 \mathrm{~g} / \mathrm{L}(59,3 \%)$, PT kéo dài $(53,7 \%)$, INR > 1,5 $(46,3 \%)$, tiểu câu giảm $<150.000 / \mathrm{mm}^{3}(40,7 \%)$, aPTT kéo dài $(35,2 \%)$. Sự thay đổi xét nghiệm chức

*Bệnh viện Đa khoa Trung tâm Tiền Giang

Chịu trách nhiệm chính: Nguyễn Thành Nam

Email: thanhnam@pediatrician.vn

Ngày nhận bài: 17.3.2021

Ngày phản biên khoa hoc: 13.5.2021

Ngày duyệt bài: 19.5.2021

\section{Nguyễn Thành Nam*, Tạ Văn Trầm*}

năng đông máu và mức độ nhiễm độc có mối tương quan có ý nghĩa thống kê, $p<0,001$. Kết luận: Ớ những bệnh nhân có độ sưng nề vết thương lan rộng qua 2 khớp có tỉ lệ nhiễm độc mức độ nặng cao gấp 2,8 lần (KTC 95\%: 1,5 - 5,1), sự khác biệt có ý nghĩa thống kê, $p<0,001$

Tư khóa: rắn cắn, rắn chàm quạp, huyết thanh kháng nọc rắn.

\section{SUMMARY}

CLINICAL AND SUBCLINICAL

CHARACTERISTICS OF CHILDREN WITH MALAYAN PIT VIPER BITES HOSPITALIZED IN CHILDREN HOSPITAL 1

Objectives: Determination of clinical and subclinical characteristics of children with malayan pit viper bites hospitalized in Children hospital 1 . Methods: Descriptive study was conducted on 54 medical records of children with snake bites hospitalized in Children hospital 1 from 01/01/2011 to $31 / 12 / 2020$. Results: Nearly $100 \%$ of cases of swelling and pain immediately, toxic hook marks $72.2 \%$. The incidence of infection and wound necrosis was quite high (37.0\% and $38.9 \%$ ). $44.4 \%$ appeared blisters and when there were blisters, $100 \%$ had hemorrhages in blisters. There is a correlation between blisters, infections, necrosis with the degree of intoxication ( $p<0.001$ ). $55.6 \%$ bruising, $46.3 \%$ bleeding, $46.3 \%$ skin hemorrhaging, gum bleeding $14.8 \%$, digestive bleeding $1.9 \%$, oliguria $(1.9 \%)$, lowering blood pressure $(1.9 \%)$ mainly seen in patients with severe infection. There is a correlation between bruising, bite bleeding, skin hemorrhage with 
a degree of intoxication ( $p<0.001)$. The wound spreads through 2 joints by $55.5 \%$. Blood clot disorder is a common manifestation of $94.6 \%$, of which DIC accounted for $57.5 \%$ with fibrinogen down < $1 \mathrm{~g} / \mathrm{L}$ (59.3\%), prolonged PT (53.7\%), INR > $1.5(46.3 \%)$, platelet $<150,000 / \mathrm{mm}^{3}(40.7 \%)$, prolonged aPTT $(35.2 \%)$. The change in blood clot function testing and the degree of toxicity have a statistically significant correlation, $p<0.001$. Conclusions: In children with wound swelling spreading through 2 joints, the incidence of severe intoxication is 2.8 times higher (KTC 95\%: 1.5 - 5.1), statistically significant difference, $\mathrm{p}<0.001$

Keywords: snake bite, Malayan pit viper, antisnake venom.

\section{I. ĐẶT VẤN ĐỀ}

Rắn độc cắn là một tai nạn phổ biến ở Việt Nam và nhiều quốc gia trên thế giới với số trường hợp tử vong cao. Theo thống kê của Tổ chức $Y$ tế Thế giới, hàng năm có hơn 5.000 .000 trường hợp rắn cắn xảy ra trên thế giới, $50 \%$ là rắn độc cắn và có 81.000 đến 138.000 trường hợp tử vong và hơn 100.000 người để lại di chứng nặng nề. Đây là vấn đề cần được quan tâm nghiên cứu, nâng cao chẩn đoán, điều trị và phòng ngừa nên Tổ chức $Y$ tế Thế giới đã bổ sung trở lại bệnh lý rắn độc cắn vào danh mục các bệnh nhiệt đới bi lãng quên ${ }^{(5)}$.

Tuy chưa có số liệu công bố chính thức nhưng số bệnh nhân bị rắn cắn ở nước ta lên tới 30.000 người mỗi năm(1). Rắn chàm quạp hay còn gọi là rắn lục Mã Lai là loài rắn độc rất nguy hiểm thuộc họ rắn lục thường gây tai nạn ở các nước vùng nhiệt đới ở Đông Nam Á. Sự nguy hiểm chính là sau khi bệnh nhân bị rắn chàm quạp cắn sẽ nhanh chóng bị rối loạn đông máu, chảy máu không cầm, xuất huyết da, phủ tạng toàn thân đe dọa tử vong ${ }^{(1)}$. Đây là mối lo ngại cho học sinh, cổng dân, nông dân đồn điền cao su, cà phê miền Đông Nam Bộ vì vậy việc nắm vững các đặc điểm về lâm sàng, cận lâm sàng là hết sức cần thiết nhằm giúp bác sĩ lâm sàng xác định chẩn đoán bệnh nhi bị rắn chàm quạp cắn và chỉ định điều trị kịp thời huyết thanh kháng nọc rắn. Chúng tôi tiến hành đề tài nầy với mục tiêu là xác định đặc điểm lâm sàng và cận lâm sàng ở bệnh nhi bị rắn chàm quạp cắn nhập Bệnh viện Nhi đồng 1

\section{II. ĐỐI TƯợNG VÀ PHƯƠNG PHÁP NGHIÊN CỨU Đối tượng nghiên cứu \\ Dân sổ chọn mẫu: Tất cả bệnh nhi $<16$} tuổi được chẩn đoán rắn chàm quạp cắn nhập khoa Cẩp cứu Bệnh viện Nhi đồng 1 từ ngày $01 / 01 / 2011$ đến ngày $31 / 12 / 2020$.

Tiêu chuẩn lựa chọn: Người nhà đập chết rắn, mang rắn đến bệnh viện và được bác sĩ tại khoa Cấp cứu xác định là rắn chàm quạp, hoặc bệnh nhi hoặc người nhà nhìn thây rắn mô tả lại và xác định được rắn qua hình mẫu tại khoa Cấp cứu, hoặc dựa vào các triệu chứng lâm sàng, cận lâm sàng và địa điểm xảy ra tai nạn phù hợp với dịch tễ rắn chàm quạp cắn.

Tiêu chuẩn loại trừ: Không có đầy đủ dữ kiện theo bệnh án mẫu.

Phương pháp nghiên cứu

Thiết kế nghiên cứu: Mô tả loạt ca

Cỡ mẫu:Lây toàn bộ

Thu thập số liệu: Các thông tin được ghi vào phiếu điêuu tra; sử dụng bảng câu hỏi và hồ sơ bênh án.

Các bước tiến hành. Chọn danh sách tất cả các bệnh nhi bị rắn cắn nhập nhập khoa Cấp cứu Bệnh viện Nhi đồng 1 từ ngày $01 / 01 / 2011$ đến ngày $31 / 12 / 2020$. Mượn hồ sơ bệnh án tại phòng lưu trữ hồ sơ, trên cở sở tất cả bệnh nhi bị rắn cắn chỉ chọn ra hồ sơ bệnh nhi bị rắn chàm quạp cắn theo đúng tiêu chí lựa chọn rồi thu thập số liệu: ghi nhận đặc điểm lâm sàng, cận lâm sàng tại các thời điểm: lúc nhập viện, trước và sau 6 giờ truyền huyết thanh kháng nọc rắn.

Bảng 1. Phân độ nhiễm độc rắn chàm quạp cắn theo Bộ $Y$ tế(1)

\begin{tabular}{|c|c|c|c|}
\hline Dấu hiệu & Nhẹ & Trung bình & Nặng \\
\hline $\begin{array}{l}\text { Dấu hiệ̂u } \\
\text { tại chô̂ }\end{array}$ & $\begin{array}{l}\text { Có dấu răng, đau nhê, } \\
\text { sưng không quá } 01 \text { khớp, } \\
\text { vòng chi nơi lớn nhất } \\
\text { không quá } 2 \mathrm{~cm} \text { và không } \\
\text { hoại tử. }\end{array}$ & $\begin{array}{c}\text { Có dấu răng, đau, sưng tới } \\
\text { khớp thứ } 2 \text {, vòng chi nơi } \\
\text { lớn nhất } 2-4 \text { cm và hoại tử } \\
\text { nhỏ. }\end{array}$ & Có dấu răng, đau, sưng rộng. \\
\hline $\begin{array}{l}\text { Dấu hiệu } \\
\text { toàn thân }\end{array}$ & Không & $\begin{array}{c}\text { Có (lừ đừ, dấu hiệu nhiễm } \\
\text { độc) } \\
\text { Không nguy hiểm }\end{array}$ & $\begin{array}{c}\text { Dấu hiệu quá } 2 \text { khớp hoắc sưng } \\
\text { nề lan đến thân minh, vờng chi } \\
\text { nơi lớn nhất > } 4 \mathrm{~cm} \text { và hoại tữ } \\
\text { lan nguy hiểm cấp cứu (sốc, suy } \\
\text { hố hấp, rối loạn tri giác...) }\end{array}$ \\
\hline Rối loạn & Không & Rối loạn đông máu nhẹ & Rối loạn đông máu nặng \\
\hline
\end{tabular}




\begin{tabular}{|c|c|c|}
\hline \multicolumn{3}{|l|}{ đông máu } \\
\hline \multicolumn{3}{|c|}{$\begin{array}{l}\text { Đông máu nội mạch lan tỏa (DIC): tính the } \\
\text { Thrombosis and Haemostasis) dựa vào số lượ } \\
\text { ibbrinogen. Tổng điểm } \geq 5 \text { đ: chuẩn đoán DIC. }\end{array}$} \\
\hline \multicolumn{3}{|c|}{$\begin{array}{c}\text { Bảng 2. Tiêu chuẩn chẩn đoán DIC theo } \\
\text { ISTH(T) }\end{array}$} \\
\hline \multicolumn{2}{|c|}{ Chỉ số } & Điếm \\
\hline \multirow{3}{*}{$\begin{array}{l}\text { Số lượng } \\
\text { tiểu cầu }\end{array}$} & $>100 \times 10^{3} / \mathrm{mm}^{3}$ & 0 \\
\hline & $50-100 \times 10^{3} / \mathrm{mm}^{3}$ & 1 \\
\hline & $<50 \times 10^{3} / \mathrm{mm}^{3}$ & 2 \\
\hline \multirow{3}{*}{$\begin{array}{l}\text { D-Dimer so với } \\
\text { giới hạn cao bình } \\
\text { thường (dấu ấn } \\
\text { tăng tiêu fibrin) }\end{array}$} & $<0,5 \mu \mathrm{g} / \mathrm{ml}$ & 0 \\
\hline & $0,5-5 \mu \mathrm{g} / \mathrm{ml}$ & 2 \\
\hline & $>5 \mu \mathrm{g} / \mathrm{ml}$ & 3 \\
\hline \multirow{3}{*}{$\begin{array}{l}\text { Thời gian } \\
\text { prothrombin }\end{array}$} & Kéo dài $\leq 3$ giây & 0 \\
\hline & Kéo dài $>3$ và $\leq 6$ giây & 1 \\
\hline & Kéo dài > 6giây & 2 \\
\hline \multirow{2}{*}{ Fibrinogen } & $>1 \mathrm{~g} / \mathrm{l}$ & 0 \\
\hline & & \\
\hline
\end{tabular}

Xử trí số liệu. Các số liệu sẽ được mã hóa, nhập liệu và phân tích theo phương pháp thống kê y hợc, lập bảng vẽ biểu đồ, sử dụng các phần mềm EpiData Manager; Stata 16; Microsoft office 365. Sử dụng thống kê mô tả và thống kê phân tích.

Y đức. Nghiên cứu đã được hội đồng $Y$ đức Bệnh viện Nhi Đồng 1 thông qua, số 534/GCNBVNĐ1.

\section{KẾT QUẢ NGHIÊN CỨU}

Qua nghiên cứu 54 bệnh nhi bị rắn chàm quạp cắn nhập khoa Cấp cứu Bệnh viện Nhi đồng 1 từ ngày $01 / 01 / 2011$ đến ngày 31/12/2020 ghi nhận mức độ nhiễm độc nhẹ, trung bình và nặng lần lượt là $50 \%$ và $50 \%$ tại thời điểm trước truyền huyết thanh kháng nọc rắn. Đa số bênh nhi bị rắn chàm quạp cắn từ 6 tuổi trở lên chiếm $68,5 \%$, tỉ lệ nam/nữ là 1,8/1. Tai nạn xảy ra quanh năm nhất là vào những tháng mùa mưa $66,8 \%$ từ tháng 5 đến tháng 11 . $77,8 \%$ bị cắn trong khoảng thời gian từ 12 giờ đến 24 giờ. Bình Phước là địa phương có bệnh nhi bị rắn chàm quạp cắn nhập viện nhiều nhất $(29,6 \%) .53,7 \%$ trẻ bị cắn ở xung quanh nhà và trong nhà, đa số do vô tình cắn $96,3 \%$. Hơn $70 \%$ vết cắn nằm ở chân, nhất là bàn chân $61,1 \% .57,4 \%$ trường hợp đem theo rắn sau khi bị rắn cắn, $72,2 \%$ trường hợp sơ cứu không đúng (thường gặp là garrot, rạch da, hút nặn nọc độc, đắp thuốc...). 77,7\% trường hợp nhập viện trong 24 giờ sau khi bị rắn cắn.

Bảng 3. Đặc điểm lâm sàng và mức độ nhiễm độc $(N=54)$

\begin{tabular}{|c|c|c|c|c|c|}
\hline \multirow{2}{*}{ Đặc điểm lâm sàng } & \multirow[b]{2}{*}{$\mathbf{N}(\%)$} & \multicolumn{2}{|c|}{ Đố nhiềm độc } & \multirow[b]{2}{*}{$\begin{array}{c}\text { PR } \\
\text { (KTC 95\%) }\end{array}$} & \multirow[b]{2}{*}{$\mathbf{p}$} \\
\hline & & $\begin{array}{l}\text { Nhe, trung } \\
\text { bình }(\%)\end{array}$ & $\begin{array}{l}\text { Năng } \\
N(\%)\end{array}$ & & \\
\hline \multicolumn{6}{|c|}{$\begin{array}{l}\text { Triệu chứng tại chồ } \\
\end{array}$} \\
\hline Đau tại chố & $53(98,2)$ & $27(50,9)$ & $26(49,1)$ & $1,0(0,9-1,1)$ & 0,31 \\
\hline Sưng nề & $51(94,4)$ & $24(47,1)$ & $27(52,9)$ & $1,1(0,9-1,3)$ & 0,07 \\
\hline Dấu móc độc & $39(72,2)$ & $21(53,8)$ & $18(46,2)$ & $0,9(0,6-1,2)$ & 0,36 \\
\hline Bầm máu & $30(55,6)$ & $9(30,0)$ & $21(70,0)$ & $2,3(1,3-4,1)$ & 0,001 \\
\hline Bóng nước & $24(44,4)$ & $4(16,7)$ & $20(83,3)$ & $5(2,0-12,7)$ & $<0,001$ \\
\hline Hoại tử & $21(38,9)$ & $4(19,0)$ & $17(81,0)$ & $4,3(1,6-11,0)$ & $<0,001$ \\
\hline Nhiêm trùng & $20(37,0)$ & $3(15,0)$ & $17(85,0)$ & $5,7(1,9-17,1)$ & $<0,001$ \\
\hline \multicolumn{6}{|c|}{ Triệu chứng xuất huyết } \\
\hline Chảy máu vết cắn & $25(46,3)$ & $5(20,0)$ & $20(80,0)$ & $4,0(1,8-9,1)$ & $<0,001$ \\
\hline Xuất huyết da & $25(46,3)$ & $312,0)$ & $22(88,0)$ & $7,3(2,5-21,6)$ & $<0,001$ \\
\hline Chảy máu nướu răng & $8(14,8)$ & 0 & $8(100,0)$ & & \\
\hline Tiếu máu vi thế & $3(5,8)$ & 0 & $3(100,0)$ & & \\
\hline Xuất huyết kết mạc & $1(1,9)$ & 0 & $1(100,0)$ & & \\
\hline Xuất huyết tiêu hóa & $1(1,9)$ & 0 & $1(100,0)$ & & \\
\hline \multicolumn{6}{|c|}{ Độ sưng nề vết thương } \\
\hline$\leq 2$ khớp & $24(44,4)$ & $19(79,2)$ & $520,8)$ & 1 & $<0,001$ \\
\hline$>2$ khớp & $30(55,6)$ & $8(26,7)$ & $22(73,3)$ & $2,8(1,5-5,1)$ & \\
\hline
\end{tabular}

Nhận xét: Các triệu chứng tại chồ thường gặp: đau tại chỗ $98,2 \%$, sưng nề $94,4 \%$, dấu móc độc $72,2 \%$, bầm máu $55,6 \%$. Bóng nước, hoại tử tại chỗ chiếm tỉ lệ lần lượt là $44,4 \%$ và $38,9 \%$, tỉ lệ nhiễm trùng tại chỗ chiếm $37,0 \%$. 46,3\% các trường hợp có chảy máu vết cắn và xuất huyết dưới 
da, chảy máu nướu răng 14,8\%, xuất huyết kết mạc 1,9\%, xuất huyết tiêu hóa 1,9\%. Tại thời điểm nhập viện, $88,9 \%$ vết thương sưng nề vượt qua trên 1 khớp, $44,4 \%$ vết thương sưng về vượt qua trên 2 khớp. Các triêu chứng bầm máu, bóng nước, hoai tử, nhiễm trùng, chảy máu vết cắn, xuất huyết da, độ sưng nề $>2$ khớp có sự khác biệt có ý nghĩa thống kê với $p<0,001$.

Bảng 4. Số lượng tiểu cầu TB và mức độ nhiếm độc $(N=54)$

\begin{tabular}{|c|c|c|c|c|}
\hline \multirow{4}{*}{$\begin{array}{l}\text { Số lượng tiểu câu } \\
\qquad\left(\times 10^{3} / \mathrm{mm}^{3}\right)\end{array}$} & \multirow{2}{*}{ Chung } & \multicolumn{2}{|c|}{ Độ nhiêm độc } & \multirow{3}{*}{$\mathbf{p}^{Y}$} \\
\hline & & Nhẹ, trung bình & Năng & \\
\hline & $\mathrm{TB} \pm$ ĐLC & TB \pm ĐLC & $\mathrm{TB} \pm$ ĐLC & \\
\hline & $200,4 \pm 150,8$ & $307,2 \pm 97,4$ & $93,6 \pm 114,7$ & $<0,001$ \\
\hline
\end{tabular}

Y Mann-Whitney test

Nhận xét: Số lượng tiểu câu trung bình là $200,4 \pm 150,8\left(\times 10^{3} / \mathrm{mm}^{3}\right)$, thấp nhất là 2 $\left(\times 10^{3} / \mathrm{mm}^{3}\right)$, nhiều nhất là $537\left(\times 10^{3} / \mathrm{mm}^{3}\right)$. Số lượng tiểu cầu trung bình ở 2 nhóm bệnh nhi nhiễm độc nhẹ, trung bình và nhiếm độc nặng có sự khác biệt có ý nghĩa thống kê, với $\mathrm{p}<0,001$.

Bảng 5. Thay đổi xét nghiệm chức nàng đông máu và mức độ độc (N=54)

\begin{tabular}{|c|c|c|c|c|}
\hline \multirow{2}{*}{$\begin{array}{l}\text { Các xét } \\
\text { nghiệm }\end{array}$} & \multirow{2}{*}{$\mathbf{N}(\%)$} & \multicolumn{2}{|c|}{ Độ nhiêm độc } & \multirow[b]{2}{*}{$\mathbf{p}^{\beta}$} \\
\hline & & Nhẹ, trung bình (\%) & Nặng (\%) & \\
\hline \multicolumn{5}{|c|}{ PT kéo dài (> 3s so với chứng) } \\
\hline & $29(53,7)$ & $4(13,8)$ & $25(86,2)$ & $<0,001$ \\
\hline \multicolumn{5}{|c|}{ aPPT kéo dài (> 10s so với chứng) } \\
\hline & $19(35,2)$ & $2(10,5)$ & $17(89,5)$ & $<0,001$ \\
\hline \multicolumn{5}{|c|}{ Giảm Fibrinogen ( $\leq 1 \mathrm{~g} / \mathrm{L})$} \\
\hline & $32(59,3)$ & $7(21,9)$ & $25(78,1)$ & $<0,001$ \\
\hline \multicolumn{5}{|c|}{ INR kéo dài > 1,5 } \\
\hline & $25(46,3)$ & $3(12,0)$ & $22(88,0)$ & $<0,001$ \\
\hline \multicolumn{5}{|c|}{ Số lượng tiếu câu giảm $<150\left(\times 10^{3} / \mathrm{mm}^{3}\right)$} \\
\hline & $22(40,7)$ & $2(9,1)$ & $20(90,9)$ & $<0,001$ \\
\hline
\end{tabular}

${ }^{\beta}$ Fisher's exact test

Nhận xét: Sự thay đổi xét nghiệm chức năng đông máu ở 2 nhóm bệnh nhi nhiễm độc nhẹ, trung bình và nhiễm độc nặng có sự khác biệt có ý nghĩa thống kê, với $p<0,001$.

Bảng 6. Điểm trung binh DIC và mức độ nhiếm độc $(N=54)$

\begin{tabular}{|c|c|c|c|c|}
\hline \multirow{4}{*}{ Điểm DIC } & \multirow{2}{*}{ Chung } & \multicolumn{2}{|c|}{ Độ nhiêm độc } & \multirow{3}{*}{$\mathbf{p}^{\curlyvee}$} \\
\hline & & Nhẹ, trung bình & Năng & \\
\hline & $\mathrm{TB} \pm \mathrm{DLC}$ & $\mathrm{TB} \pm$ ĐLC & $\mathrm{TB} \pm \mathrm{DLC}$ & \\
\hline & $5,0 \pm 2,5$ & $3,2 \pm 1,6$ & $6,7 \pm 1,8$ & $<0,001$ \\
\hline
\end{tabular}

Y Mann-Whitney test

Nhận xét. Điểm DIC trung bình là 5,0 $\pm 2,5$ điểm, điểm DIC trung bình ở 2 nhóm bệnh nhi nhiễm độc nhẹ, trung bình và nhiễm độc nặng có sự khác biệt có ý nghĩa thống kê, với $p<0,001$. Chức năng đông máu bất thường (1 - 8 điểm) chiếm $94,6 \%$ trường hợp, trong đó đông máu nội mạch lan tỏa (5 - 8 điểm) chiếm $57,5 \%$ các trường hợp tại thời điểm trước truyền huyết thanh kháng nọc rắn.

\begin{tabular}{|c|c|c|c|}
\hline \multirow{2}{*}{ Cận lâm sàng } & \multicolumn{3}{|c|}{ Tỉ lệ bất thường } \\
\hline & Mức độ & $\mathbf{N}$ & Tỉ lệ \\
\hline WBC $\left(\times 10^{3} / \mathrm{mm}^{3}\right)$ & $>15$ & 22 & 40,7 \\
\hline Hct (\%) & $<30$ & 8 & 14,8 \\
\hline CRP (mg/L) & $>20$ & 5 & 9,3 \\
\hline $\mathrm{Na}^{+}(\mathrm{mmol} / \mathrm{L})$ & $<130$ & 2 & 3,7 \\
\hline $\mathrm{K}^{+}(\mathrm{mmol} / \mathrm{L})$ & $<3,5$ & 7 & 13,0 \\
\hline $\mathrm{Ca}^{++}(\mathrm{mmol} / \mathrm{L})$ & $<1$ & 1 & 1,9 \\
\hline CPK (U/L) & $\begin{array}{l}>5 \text { lần bình } \\
\text { thường }\end{array}$ & 3 & 5,5 \\
\hline Creatinin $(\mu \mathrm{mol} / \mathrm{L})$ & $>150$ & 1 & 1,9 \\
\hline AST $(\mathrm{U} / \mathrm{L})$ & $\geq 120$ & 2 & 3,7 \\
\hline
\end{tabular}

\begin{tabular}{|c|c|c|c|}
\hline $\mathrm{ALT}(\mathrm{U} / \mathrm{L})$ & $\geq 120$ & 2 & 3,7 \\
\hline Hồng câu niệu & $(+)$ & 3 & 5,6 \\
\hline
\end{tabular}

Nhân xét: Đa phần bênh nhi bi rắn chàm quạp cắn ít bị rối loạn các cơ quan khác, chủ yếu gặp ở bênh nhi nhiểm độc mức độ nặng đến trễ do đi thầy lang đắp thuốc, uống thuốc nam.

\section{BÀN LUẬN}

Trong nghiên cứu của chúng tôi đa số bệnh nhi có đau tại chỗ $98,2 \%$, sưng nề $94,4 \%$, dấu móc độc $72,2 \%$, bầm máu $55,6 \%$, chảy máu vết cắn 46,3\%. Bóng nước có $44,4 \%$ trường hợp, những trường hợp bóng nước thì $100 \%$ có xuất huyết trong bóng nước. Nhiễm trùng và hoại tử do rắn chàm quạp cắn chiếm tỉ lệ khá cao 37,0\% 
và $38,9 \%$. Theo bài viết của tác giả Arnuparp Lekhakula đăng trên tạp chí $Y$ học Truyên máu và Huyết học Thái Lan năm 2014, nghiên cứu 411 bệnh nhi bị rắn chàm quạp cắn tại Bệnh viện Songkhla Nakarinthorn, trong nhóm nhiễm đồc nặng ghi nhận sưng nề $100 \%$, bóng nước $39,0 \%$, xuất huyết dưới da $27,0 \%$, chảy máu vết cắn $28 \%$ và hoại tử $13 \%{ }^{(4)}$. So với nghiên cứu của Mã Tú Thanh trên rắn lục tre, các triêu chứng tại chỗ thường gặp là sưng nề $100 \%$, đau tại chỗ $100 \%$, dấu móc độc $92,6 \%$, bóng nước, hoại tử - nhiếm trùng vết thương, chảy máu vết cắn ít gặp hơn lần lượt là $13,5 \%, 4,7 \%$ và $4,1 \%$ thấp hơn nghiên cứu của chúng tôi vì nọc rắn chàm quạp có nhiêu độc tố (proteolytic enzyme, phospholipase, hyaluronidase, metalloproteinases...) gây hủy hoại màng tế bào nội mô, ly giả tế bào, phá hủy mô, gây hoại tử, xuất huyết trong bóng nước, bóng nước vỡ dẫn đễn nhiễm trùng thứ phát tại vết cắn (3)

Trong nghiên cứu của chúng tôi ghi nhận chảy máu vết cắn $46,3 \%$, xuất huyết da $46,3 \%$, chảy máu nướu răng $14,8 \%$, tiểu máu vi thể $5,8 \%$ và 1 trường hợp có xuất huyết kết mạc và xuất huyết tiêu hóa (1,9\%). Theo Arnuparp Lekhakula nghiên cứu trên 411 bệnh nhân bị rắn chàm quạp cắn tại Bệnh viện Songkhla Nakarinthorn ghi nhận chảy máu nướu răng $43,6 \%$, xuất huyết dưới da $33,3 \%$, xuất huyết trong cơ 36,9\%, xuất huyết tiêu hóa $20,5 \%$, xuất huyết đường tiết niệu $20,5 \%$ và $7,7 \%$ có xuất huyết não(4). So với nghiên cứu của Mã Tú Thanh, tỉ lệ xuất huyết do rắn chàm quap cắn cao hơn nhiều so với rắn lục tre, chảy máu vết cắn $5,4 \%$, xuất huyết da $4,7 \%$, chảy máu nướu răng $1,4 \%$ và tiểu máu vi thể $0,7 \%{ }^{(3)}$. Các triêuu chứng tai chỗ như bóng nước, bầm máu, nhiễm trùng tại chỗ, hoại tử với mức độ nhiễm độc đều có tươning quan, có ý nghĩa thống kê. ờ những bệnh nhi có nổi bóng nước thì có tỉ lệ nhiễm độc mức độ nặng cao gấp 5,0 lần (KTC 95\%: 2,0 $12,7), p<0,001$. Ở những bệnh nhi có bầm máu thì có tỉ lệ nhiễm độc mức độ nặng cao gấp 2,3 lần (KTC 95\%: 1,3-4,1), $\mathrm{p}=0,001$. Ở những bênh nhi có nhiếm trùng tại chỗ thì có tỉ lệ nhiễm độc mức độ nặng cao gấp 5,7 lần (KTC $95 \%: 1,9-17,1), \mathrm{p}<0,001$. Ở những $\mathrm{BN}$ có hoại tử thì có tí lệ nhiễm độc mức độ nặng cao gấp 4,3 lần (KTC 95\%: 1,6-11,0), $p<0,001$. Các triệu chứng xuất huyết như chảy máu vết cắn, xuất huyết da với mức độ nhiễm độc cho thấy tương quan, có ý nghĩa thống kê. ở những bênh nhi có chảy máu vết cắn thì có tỉ lệ nhiễm độc mức độ nặng cao gấp 4,0 lần (KTC 95\%: 1,8
$-9,1), p<0,001$. Ở những bệnh nhi có xuất huyết da thì có tỉ lệ nhiễm độc mức độ nặng cao gấp 7,3 lần (KTC 95\%: 2,5 - 21,6), $p<0,001$.

Tại thời điểm trước khi truyền huyết thanh kháng nọc rắn $92,6 \%$ vết thương sưng nề vượt qua trên 1 khớp, 55,5\% vết thương sưng nề vượt qua trên 2 khớp. Theo tác giả Mã Tú Thanh, tại thời điểm nhập viện $96,5 \%$ vết thương sưng nề vượt qua 1 khớp, tại thời điểm ngay trước truyền huyết thanh kháng nọc rắn $99,3 \%$ vết thương sưng nề vượt qua trên 2 khớp ${ }^{(3)}$. Có sự khác biệt giữa trẻ em và người lớn khi bị rắn cắn là tỉ lệ lượng nọc độc đưa vào cơ thể so với tích máu của nạn nhân ở trẻ em lớn hơn người lớn do đó độc tính nọc rắn tác động lên trẻ em sẽ tăng cao hơn so với người lớn, vì thế mà độ lan rộng tổn thương tại chỗ trong nghiên cứu chúng tôi khá nặng.

Trong nghiên cứu của chúng tôi ghi nhận bất thường chức năng đông máu (1 - 8 điểm) chiếm $94,6 \%$ trường hợp, trong đó DIC ( 5 - 8 điểm) chiếm $57,5 \%$ tại thời điểm trước truyền huyết thanh kháng nọc rắn. Điểm DIC trung bình là 5,0 $\pm 2,5$ điểm, điểm DIC ở nhóm nhiễm độc nặng là $6,7 \pm 1,8$ điểm. Có sự khác biệt có ý nghĩa thống kê điểm DIC ở 2 nhóm nhiễm độc nhẹ, trung bình và nhóm nhiễm độc nặng với $p<$ 0,001 . Nghiên cứu của Mã Tú Thanh trên rắn lục tre cho thấy $85,1 \%$ có bất thường chức năng đông máu, $29,7 \%$ có hội chứng DIC ${ }^{(3)}$, thấp hơn trong nghiên cứu của chúng tôi, do nọc rắn chàm quạp có các enzym có hoạt tính gây rối loạn đông máu, độc tố serin gây rối loạn đông máu, snaclec rhodocetin làm tiểu cầu giảm, rhodostoxin làm trung gian xuất huyết, kistomin và snaclec rhodocetin làm tình trạng xuất huyết nặng hơn.

Số lượng tiểu cầu giảm dưới $150 \times 10^{3} / \mathrm{mm}^{3}$ chiếm $40,8 \%$, trong đó tiểu câu giảm dưới $100 \times 10^{3} / \mathrm{mm}^{3}$ chiếm $35,2 \%$ các trường hợp bị rắn chàm quap cắn tai thời điểm ngay trước truyền huyết thanh kháng nọc rắn. Theo Mã Tú Thanh có $12,9 \%$ trường hợp có số lượng tiểu cầu giảm dưới $150 \times 10^{3} / \mathrm{mm}^{3}, 4,1 \%$ có số lượng tiểu cầu giảm dưới $50 \times 10^{3} / \mathrm{mm}^{3(3)}$. Số lượng tiểu cầu trung bình là $200,4 \pm 150,8$ $\left(\times 10^{3} / \mathrm{mm}^{3}\right)$, thấp nhất là $2 \times 10^{3} / \mathrm{mm}^{3}$, nhiêu nhất là $537 \times 10^{3} / \mathrm{mm}^{3}$. Số lượng tiểu cầu trung bình ở 2 nhóm nhiễm độc nhẹ, trung bình và nhiễm độc nặng có sự khác biệt có ý nghĩa thống kề, với $\mathrm{p}<0,001$. Tác giả Arnuparp Lekhakula, số lượng tiểu cầu trung bình ở 2 nhóm nhiếm độc trung bình và nhiễm độc nặng lần lượt là $173,3 \pm 74,2\left(\times 10^{3} / \mathrm{mm}^{3}\right)$ và 45,6 \pm 
$78,6\left(\times 10^{3} / \mathrm{mm}^{3}\right)^{(4)}$. Số lượng tiểu cầu càng giảm thì mức độ của bệnh càng nặng.

Trong nghiên cứu của chúng ghi nhận, bất thường xét nghiệm đông máu toàn bộ tại thời điểm trước truyền huyết thanh kháng nọc rắn chiếm tỉ lệ từ cao nhất đến thấp nhất lần lượt là Fibrinogen giảm < $1 \mathrm{~g} / \mathrm{L}(59,3 \%)$, thời gian đông máu ngoại sinh (PT) kéo dài $(55,8 \%)$, INR kéo dài $(46,3 \%)$, thời gian đông máu nội sinh (aPTT) kéo dài $(35,2 \%)$. Theo nghiên cứu của Mã Tú Thanh và Lê Thị Thùy Linh, tỉ lệ Fibrinogen giảm $<1 \mathrm{~g} / \mathrm{L}$, thời gian đông máu ngoại sinh (PT) kéo dài, thời gian đông máu nội sinh ( $\mathrm{aPTT}$ ) kéo dài lần lượt là $29,1 \%, 25,0 \%, 12,2 \%$ và $26,4 \%$, $18,4 \%, 12,6 \%(2,3)$. Một số tác giả Thái Lan như Kanthika Kraisawat, Arnuparp Lekhakula ghi nhận tình trạng rối loạn đông máu lần lượt là $38,6 \%$ và $59,26 \%(4,6)$. Trong số bệnh nhi có fibrinogen giảm $<1 / L$, ở nhóm nhiễm độc nặng là 25/32 BN $(78,1 \%)$, nhóm nhiễm độc nhẹ, trung bình là $7 / 32(21,9 \%)$, sự khác biệt có ý nghĩa thống kê với $\mathrm{p}<0,001$. Theo Mã Tú Thanh, ở nhóm nhiễm độc nặng là 76,1\%, nhóm nhiễm độc nhẹ, trung bình là $22,2 \%{ }^{(3)}$. Có $55,8 \%$ trường hợp có PT kéo dài, kéo dài hơn chứng từ 6 giây trở lên chiếm 48,2\%, PT kéo dài ở nhóm nhiễm độc nặng là 25/29 (86,2\%), nhóm nhiễm độc nhẹ, trung bình là 4/29 $(13,8 \%)$, sự khác biệt có ý nghĩa thống kê với p $<0,001$. Theo Mã Tú Thanh, ở nhóm nhiễm độc nặng là $69,5 \%$, nhóm nhiếm độc nhẹ, trung bình là $30,5 \%{ }^{(3)}$. INR kéo dài $>1,5$ có $25 / 54(46,3 \%)$ trường hợp, INR kéo dài ở nhóm nhiếm độc nặng là $22 / 25(88,0 \%)$, nhóm nhiễm độc nhẹ, trung bình là $3 / 25(12,0 \%)$, sự khác biệt có ý nghĩa thống kê với $p<0,001$. Có 35,2\% trường hợp có $\mathrm{aPTT}$ kéo dài, aPTT kéo dài ở nhóm nhiễm độc nặng là $17 / 19(89,5 \%)$, nhóm nhiễm độc nhẹ, trung bình là $2 / 19(10,5 \%)$, sự khác biệt có ý nghĩa thống kê với $p<0,001$. Theo Mã Tú Thanh, ở nhóm nhiễm độc nặng là $88,9 \%$, nhóm nhiếm độc nhẹ, trung bình là $11,1 \%$ (3).

Qua nghiên cứu 54 bệnh nhi cho thấy: bạch cầu tăng $>15.000 / \mathrm{mm}^{3}$ chiếm tỉ lệ $40,7 \%$, trong đó bạch cầu trong nhóm nhiễm độc nặng là $63,6 \%$, những bệnh nhi này thường nhập viện trế, sơ cứu ban đầu không đúng, là yếu tố thuận lợi gây nhiễm trùng thứ phát về sau. Thiếu máu trung bình đến nặng (Hct < 30\%) chiếm 14,8\%, trong đó ở nhóm nhiểm độc nặng chiếm $87,5 \%$, sự khác biệt có ý nghĩa thổng kê, $p=0,03$, bệnh nhi nhiễm độc càng nặng có nguy cơ thiếu máu từ trung bình trở lên. Rắn chàm quạp cắn chủ yếu gây rối loạn đông máu, gây chảy máu nên khi xảy ra trên cơ địa bệnh nhi dễ dẫn đến thiếu máu. CRP tăng > 20mg/dL chiếm 9,3\%, natri máu giảm < $130 \mathrm{mmol} / \mathrm{L}$, tăng men gan AST, ALT > 120 U/L chiếm 3,7\%, kali máu giảm < 3,5 $\mathrm{mmol} / \mathrm{L}$ chiếm $13,0 \%$, hồng cầu niệu $(+)$ chiếm $5,6 \%, \mathrm{CPK}>5$ lần bình thường chiếm 5,5\%, 1 trường hợp suy thận cấp với creatinine $>150$ $\mu \mathrm{mol} / \mathrm{L}(1,9 \%)$ đa phần đều gặp ở bệnh nhi nhiễm độc mức độ nặng.

\section{KẾT LUÂ̂N}

Gần $100 \%$ trường hợp sưng nề, đau tại chỗ, dấu móc độc $72,2 \%$. Tỉ lệ nhiềm trùng và hoại tử vết thương khá cao $(37,0 \%$ và $38,9 \%)$. $44,4 \%$ xuất hiện bóng nước, và khi có bóng nước thì hầu hết có xuất huyêt trong bóng nước. Bầm máu $55,6 \%$, chảy máu vết cắn $46,3 \%$, xuất huyết da $46,3 \%$, chảy máu nướu răng $14,8 \%$, xuất huyết tiêu hóa $1,9 \%$, thiểu niệu $(1,9 \%)$, hạ huyết áp $(1,9 \%)$ chủ yếu gặp ở bệnh nhi nhiếm độ nặng. Vết thương lan rộng qua 2 khớp $55,5 \%$, có mối tương quan giữa độ lan rộng của vết thương với mức độ nhiểm độc $(p<0,001)$. Rối loạn chức năng đông máu là biểu hiện thường gặp $94,6 \%$, trong đó DIC chiếm $57,5 \%$ với fibrinogen giảm $<1 \mathrm{~g} / \mathrm{L}(59,3 \%)$, PT kéo dài $(53,7 \%)$, INR > 1,5 (46,3\%), tiểu cầu giảm < $150.000 / \mathrm{mm}^{3}(40,7 \%)$, aPTT kéo dài $(35,2 \%)$. Sự thay đổi xét nghiệm chức năng đông máu ở 2 nhóm nhiễm độc nhẹ, trung bình và nặng có mối tương quan có ý nghĩa thống kê, $\mathrm{p}<0,001$. Bạch cầu > 15.000/mm $\mathrm{mm}^{3}(40,7 \%)$, Hct < $30 \%$ $(14,8 \%)$, CRP tăng $>20 \mathrm{mg} / \mathrm{dL}(9,3 \%)$, natri máu < $130 \mathrm{mmol} / \mathrm{L}(3,7 \%)$, tăng men gan AST, ALT > 120U/L (3,7\%), kali máu < 3,5 mmol/L $(13,0 \%)$, hồng câuu niệu $(+)(5,6 \%), C P K>5$ lần bình thường $(5,5 \%), 1$ trường hợp suy thận cấp với creatinine $>150 \mu \mathrm{mol} / \mathrm{L}(1,9 \%)$ đa phẩn đều gặp ở bệnh nhi nhiễm độc mức độ nặng. Ngành $Y$ tế nên thường xuyên có những chương trình tập huấn cho cán bộ y tế các tuyến cơ sở về việc nhận diện các loài rắn độc, đặc điểm tổn thương do chúng gây ra, các biện pháp điều trị được khuyến cáo, và đưa vào sử dụng huyết thanh kháng nọc rắn chàm quạp ở tuyến trước vừa đạt mục tiêu điều trị sớm cho bệnh nhi vừa tránh mất thời gian và chi phí cho việc chuyển bệnh lên tuyến trên.

\section{TÀI LIẸU THAM KHẢO}

1. Bộ Y Y tế (2017) Hướng dẫn chẩn đoán và xử trí ngộ độc, Nhà xuất bản Y học, Hà Nội, tr.89-124.

2. Lế Thị 'Thùy Linh (2016) "Tình hình sử dung huyết thanh kháng noc rắn tại Bệnh viện Nhi Đống 2 từ năm 2010 đến 2014". Tạp chí Y học TP. Hồ Chí Minh, 20 (4), tr.79-86. 
3. Mã Tú Thañh, Phạm Văn Quang (2017) "Đặc điểm dich tễ, lâm sàng, cân lầm sàng ở bênh nhi bị rắn lục tre cắn tại Bệnh viện Nhi Đồng 1 ". Tạp chí Y học TP. Hồ Chí Minh, 21 (4), tr.252-259.

4. Arnuparp Lekhakula (2014) "Management of Malayan Pit Viper Bites". Journal of Hematology and Transfusion Medicine, 24, 163-73.

5. Soumyadeep Bhaumik, Soushieta Jagadesh, Zohra Lassi (2018) "Quality of WHO guidelines on snakebite: the neglect continues". BMJ global health, 3 (2), e000783-e000783.
6. Kanthika Kraisawat, Nattaya Promwang (2020) "Duration after Malayan Pit Viper Bite to Detect Coagulopathy in Songklanagarind Hospital". Journal of Health Science and Medical Research, 38, 93-101.

7. Cheng $H$. Toh, Yasir Alhamdi, Simon $T$. Abrams (2016) "Current Pathological and Laboratory Considerations in the Diagnosis of Disseminated Intravascular Coagulation". Annals of laboratory medicine, 36 (6), 505-512.

\section{ĐÁNH GIÁ THỜI GIAN SỐNG THÊM UNG THƯ DA DÀY Ở NGƯờI CAO TUỔI SAU PHẪU THUÂ̂T PHỐI HỢP HÓA CHẤT PHÁC ĐỒ EOX}

\section{TÓM TẮT}

Mục tiêu: Đánh giá thời gian sống thêm của ung thư da dày ở người cao tuổi sau phẫu thuât phối hợp hóa chất phác đồ EOX. Phương pháp nghiên cứu: Nghiên cứu can thiệp lâm sàng không đối chứng có theo dõi dọc, kết hợp tiến cứu và hồi cứu. Gồm 57 bệnh nhân là người cao tuổi được chẩn đoán xác định là ung thư dạ dày giai đoạn IIa-İIIc được điều trị phẫu thuật tai bệnh viện $K$ và bệnh viện $E$ từ tháng $1 / 2009$ đến tháng 12/2019. Kết quả Thời gian sống thêm toàn bộ chung của nhóm nghiên cứu 3 năm là $85,6 \%$, 4 năm là $59,7 \%, 5$ năm là $46,7 \%$. Thời gian sống thêm toàn bộ trung bình là 49,7 $\pm 1,8$ tháng. Thời gian sống thêm không bệnh tích lũy 3 năm là $63,5 \%, 4$ năm là $45,8 \%, 5$ năm là $35,6 \%$. Thời gian sống thêm không bệnh trung bình là 44,4 $\pm 2,1$ tháng. Bệnh nhân có bệnh tim mạch kèm theo có thời gian sống thêm trung bình là $37,45 \pm 3,5$ tháng thấp hơn so với thời gian sống thêm trung bình của nhóm không có bênh tim mach kèm theo $(51,8 \pm 1,8$ tháng). Kết luân: Hóa trị bổ trợ phác đồ EOX đem lại lợi ích sống thềm trên bệnh nhân cao tuổi ung thư da dày đã phấu thuật triệt căn có nguy cơ cao.

Tư khóa: Ung thư da dày; phác đồ EOX; thời gian sống thêm, người cao tuổi.

\section{SUMMARY \\ EVALUATION ON SURVIVAL TIME AFTER SURGERY AND EOX REGIMEN CHEMOTHERAPY TO TREAT GASTRIC CANCER IN ELDERLY PATIENTS}

Objectives: to evaluate the survival time after surgery and EOX regimen chemotherapy to treat gastric cancer in elderly patients. Subjects and methods: Non-controlled clinical interventional study

\section{${ }^{1}$ Bênhh viện $E$}

Chiu trách nhiệm chính: Lê Thành Trung

Email: bslethanhtrung@yahoo.com

Ngày nhận bài: 15.3.2021

Ngày phản biên khoa học: 12.5 .2021

Ngày duyệt bài: 19.5.2021

\section{Lê Thành Trung ${ }^{1}$, Đoàn Hữu Nghị ${ }^{1}$}

with vertical follow-up, with a combination of prospective and retrospective study was conducted on 57 elderly patients diagnosed with gastric cancer staged IIa - IIIc and undergoing surgical treatment at K Hospital and E hospital from January, 2009 to December, 2019. Results: Overall survival rate of the study groups of 3 years was $85.6 \%$, of 4 years was $59.7 \%$, of 5 years was $46.7 \%$. The mean overall survival time was $49.7 \pm 1.8$ months. The disease-free survival rate of 3 years was $63.5 \%$, 4 years was $45.8 \%, 5$ years was $35.6 \%$. The mean disease-free survival time was $44.4 \pm 2.1$ months. Patients with comorbid conditions of cardiovascular disease had a median survival time of $37.45 \pm 3.5$ months, which was lower than the mean survival time of the group without comorbid conditions of cardiovascular disease (51.8 $\pm 1,51.8 \pm 1.8$ months). Conclusions: Adjuvant chemotherapy EOX regimen improved survival time in patients with gastric cancer after radical surgeries.

Keywords: gatric cancer, EOX regimen, survival time, elderly.

\section{I. ĐẶT VẤN ĐỀ}

Tại Việt nam theo Globocan 2018, UTDD đứng thứ 3 ở cả hai giới sau ung thư gan và ung thư phổi với tỷ lệ mắc chuẩn theo tuổi là 11,38/100.000 dân. Trong đó, loại ung thư biểu mô tuyến chiếm chủ yếu (90-95\%) [1].

Trong điều trị ung thư dạ dày, phẫu thuật được xem là phương pháp điêuu trị chính. Các nghiên cứu ở nước ta cho thấy đa số bệnh nhân được chẩn đoán ở giai đoạn bệnh tiến triển, thường xuất hiện tái phát, di cằn sau khi đã được phẫu thuật [2]. Mặc dù kỹ thuật phẫu thuật ung thư dạ dày ngày càng tiến bộ, nhưng kết quả sống thêm toàn bộ của bệnh nhân ung thư da dày giai đoạn tiến triển vẩn thấp, tỷ lể sống 5 năm chỉ đạt 25-45\% [3], [4]. Chính vì vậy, để cải thiện tiên lượng của ung thư dạ dày giai đoạn tiến triển, ngoài hoàn thiện phương pháp phẫu thuật điều trị triệt căn cổ điển, hiện 